\title{
THE ROLE OF VERTICAL HOLINESS IN THE MULTI- STOREY INFRASTRUCTURE DESIGN
}

\author{
I Made Sastra Wibawa ${ }^{1,2)}$, I Wayan Redana1), Putu Alit Suthanaya'), dan Ngakan \\ Made Anom Wiryasa ${ }^{1)}$
}

1) Doctoral Program in Engineering, Udayana University, Denpasar, Indonesia

2) Civil Engineering, Mahasaraswati Denpasar University, Denpasar, Indonesia

sastrawibawa@gmail.com

\begin{abstract}
The increasing number of residents demands the provision of settlement facilities and infrastructure. Limited land is an obstacle to the development in the horizontal direction, especially the use of green open land which will cause land conversion. The limitation of the building height regulated by local regulations, as well as the local wisdom, namely vertical holiness can be a challenge related to the idea of building multi-storey buildings. When you want to enter the lower floors of the building, there is a feeling of doubt because there are other residents on the upper floors who step over. This study aims to reveal the relationship of vertical holiness with multi-storey building design and formulate vertical holiness as an effort to implement it in a design so that it can be accepted by the community. This study uses a methodology to examine the problem by interviewing the stakeholders and filling out the questionnaire, therefore, the relationship between vertical holiness and multi-storey building design can be obtained. The results of the study clearly confirm that there is indeed a correlation between vertical holiness and multi-storey building design. Thus, the design should pay attention to this vertical holiness. The study also encourages that the formulation of vertical holiness should be legally stated in regulation so that it is easily understood and accepted by the community.
\end{abstract}

Keywords: vertical holiness, multi-storey building, watery 


\begin{abstract}
ABSTRAK
Meningkatnya jumlah penduduk menuntut penyediaan fasilitas dan infrastruktur pemukiman. Keterbatasan lahan merupakan kendala bagi pengembangan ke arah horizontal, terutama penggunaan lahan terbuka hijau yang akan menyebabkan konversi lahan. Keterbatasan ketinggian bangunan diatur oleh peraturan daerah, serta kearifan lokal, yaitu kesucian vertikal dapat menjadi tantangan terkait dengan ide membangun gedung bertingkat. Saat ingin memasuki lantai bawah bangunan, ada perasaan ragu karena ada penghuni lain di lantai atas yang melangkah. Penelitian ini bertujuan untuk mengungkap hubungan kesucian vertikal dengan desain bangunan bertingkat dan merumuskan kesucian vertikal sebagai upaya untuk mengimplementasikannya dalam desain sehingga dapat diterima oleh masyarakat. Penelitian ini menggunakan metodologi untuk memeriksa masalah dengan mewawancarai para pemangku kepentingan dan mengisi kuesioner, oleh karena itu, hubungan antara kesucian vertikal dan desain bangunan bertingkat dapat diperoleh. Hasil penelitian dengan jelas mengkonfirmasi bahwa memang ada korelasi antara kesucian vertikal dan desain bangunan bertingkat. Dengan demikian, desain harus memperhatikan kesucian vertikal ini. Studi ini juga menganjurkan bahwa perumusan kesucian vertikal harus dinyatakan secara hukum dalam peraturan sehingga mudah dipahami dan diterima oleh masyarakat.
\end{abstract}

Kata kunci: kesucian vertikal, bangunan bertingkat, berair 


\section{INTRODUCTION}

\subsection{Background}

Local wisdom in the community must always be maintained so that it continues to exist and develop as an effort to preserve the noble heritage of its predecessors. Vertical holinessis one of the noble heritages which has been already developed in Balinese society even though nowadays in the development of Civil Engineering infrastructure it is not a plot that eventually becomes an obstacle. People who have a certain view of vertical purity often reject the existence of multilevel Civil Engineering development such as multi-storey buildings or flats. On the other hand, there are some people who do not care about this problem or have different perspectives so that they take for granted the construction of existing multistorey buildings. This is what ultimately can lead to the occurrence of pros and cons in society; therefore, a solution is needed that can minimize or eliminate the differences.

Multi-storey buildings by some communities can be used as an effort to suppress land use that always widens horizontally, or which in this era often causes land conversion. As the result of the increase in population, it is certain to demand the development of other sectors, especially the need for housing. With the addition of residential area, it is definitely necessary to add the land needed for the area to build a new building. If this is not strictly controlled by the authorities, there will be land conversion, and another serious problem is when the green open land is used as a residential area. Moreover, there has been a regional regulation that regulates the height of buildings, namely the Regional Regulation of Bali Province Number 16 Year 2009, which regulates the height of a multistorey building that cannot exceed fifteen meters.

The construction of multi-storey buildings is expected to be able to maintain the existing area of green open space, and residential areas that seem slum can be arranged so that it looks neat, beautiful, and comfortable. The different opinion that often arises is when the operation of this multi-storey building. There are some people who do not want to go to the floor below because they have an opinion that on the upper floors, there are other people. Those on the lower floor seem to be stepped over by the ones on the upper floor, and there was a feeling of exhaustion because it was on the lower floor. This is the reality that should be sought out so that land conversion can be suppressed, but 
those who feel a sense of weakness do not feel too disadvantaged.

Deep understanding of vertical holiness is needed because this is a local wisdom, so the input from related stakeholders is very much needed such as elders, sulinggih/pinandita or those who concern with this problem. There is a concept of vertical sanctity found in some palms as high as at least Twelve Guli and there is also at least one cubit/one arm above the crown. With the existence of these problems and the discovery of several concepts of vertical sanctity limits, it is deemed necessary to conduct a more in-depth study so as to minimize the pros and cons that occur.

\subsection{Research Problem}

Based on the background description of the above problems, the research problem can be clearly stated as follows:

1. How is the relationship between vertical holiness and height of each room/floor of a multistorey building?

2. How is the formula of vertical holiness height associated with the height of each storey building?

3. How is the alternative design of a multi-storey building so that the pros and cons can be minimized?

\subsection{Purpose of the Research}

This study aims to answer the research problems related to the vertical holiness in relation to multi-storey building design such as:

1. To find out the relationship between vertical holiness and height of each room/floor of a multi-storey building.

2. To figure out the exact formula of vertical holiness height associated with the height of each storey building.

3. To find out the alternative design of a multi-storey building so that the pros and cons can be minimized.

\section{LITERATURE REVIEW}

\subsection{Development of Multi-storey Buildings}

A multi-storey building is a civil engineering infrastructure that is not large and it has different levels of floor elevation with each other. As what has been explained by Sullivan and Arthur (2003), civil infrastructure is a basic physical need for organizing a structural system to ensure that the economy can function properly. The existence of local wisdom that limits 
the height of multi-storey buildings in Bali causes the quite slow development of infrastructure. Coupled with the existence of a different understanding of the limits of high vertical holiness, the development of multi-storey buildings is slowing down.

The Regional Government of Bali (2009), clearly states in Bali Provincial Regulation Number 16 Year 2009 concerning Bali Province Spatial Planning 2009 to 2029 regulates that high utilization of air space above the earth's surface is limited to a maximum of 15 meters, except public buildings and buildings specifically for the sake of safety and security.

The construction of a multi-storey building will probably raise the question on how the arrangement of flowering plants on the upper floors of the building will be done. This fact is a demand for the existence of thermal comfort, cool atmosphere, and efforts to meet the oxygen needs in the body. The question was answered by a study conducted by Medl et al. (2017), who confirm that to achieve thermal comfort in urban areas with multistorey buildings can be done with a vertical greening system that is affixed to the walls of the building. This fact can occur because the heat pressure will be reduced due to the green color of the plant attached to the wall and the most advantageous is that no land is taken to the side.

\subsection{Factors for the Development of Multi-storey Buildings}

The development of multi-storey buildings is strongly influenced by the demands due to the increasing population. Provision of residential facilities is the main requirement in life because it is a primary need. As the result of the developments in various things, the demand for increasing residential facilities is not only in terms of quantity but also quality in accordance with the existing legality, a sense of security, and comfortability for the residents.

In accordance with what has been stated in Law Number 16 Year 1985 which regulates flats clearly states that flats are defined as a multi-storey building which is built in an environment divided into functionally structured parts in horizontal and vertical directions and is a one unit, each of which can be owned and used separately, especially for residential areas equipped with shared parts, shared objects and shared land. Thus, flats have the same meaning as a multi-storey building, and both carry out a mission to open more green open spaces.

A study conducted by Feng (2011), by measuring the sound insulation 
performance of homes in Taiwan compared field sound insulation with the standards used by ISO 140-4 and 1407 . The buildings studied were houses with concrete floors, cement mortar and tiles. The results of the study show that there are differences in field sound isolation from 5 to $9 \mathrm{~dB}$ which indicates that housing space is affected by lateral sound from the corridor; therefore, the suggestion that is put forward is the need to increase field work isolation with surface materials of floor and ceiling decoration.

Similar research was conducted in Shah Alam, Selangor, Malaysia by Fairus et al. (2001), who conducted studies in several multi-storey buildings with different characters which had two opposite sides. One building has two sides that are exposed to the outside environment, and other buildings that are on both sides share a wall with a house next to it (close). The results of his research show that closed buildings have greater pollution than open buildings. Other researchers, Wan et al. (2011), in an experimental study simulated a number of methods in passive environmental conditions of multi-storey houses built in a row, where the weather/climate variables, residents were made constant. This simulation shows that the room in a row house creates thermal discomfort eight times longer than passive architecture every year. The advice proposed in this study is to require additional environments such as landscape and natural ventilation settings.

\subsection{Values of Vertical holiness in Spatial Scope}

Values of vertical holiness will be taken into consideration if we pass or enter the bottom floor of a multi-storey building. Beginning with a feeling of hesitation to enter, there is a feeling of awkwardness, or coupled with the feeling of being lethargic if going into the lower floors. Thus, the values of vertical holiness need to be calculated. A discussion about vertical holiness can be said to be a new thing that is bold enough to be put forward so that this great hope can provide a positive picture of the doubts of some people to enter the lower floors of multi-storey buildings. Understanding the vertical holiness height is not as high as the space that exists, or also not as far as the eye can see, but as stated in the holy library in Bali (Anonymous, LontarPurwaka Veda), (Anonim, Lontar Surya Sewana), (Anonymous, Lontar Surya Mandala). In accordance with the explanation by the owners of palm leaves, that the definite limit of vertical holiness is already 
contained in his palm leaf and has been applied in the implementation of activities especially ceremonies and upakara in Hinduism.

\subsection{Vertical Holiness According to Balinese Cultural Values}

Vertical holiness in the spatial concept is a manifestation of cultural philosophy originating from the religious philosophy of the cosmos imbued by Hinduism. Humans and nature are seen as a unit that has the same elements; therefore, when humans want to achieve their life goals, it must be done through efforts to align themselves with the surrounding environment. This is believed by the Hindu community to be able to harmonize the relationship between the psyche and the natural world through symbols, as a manifestation of the relationship between the macro nature and the micro cosmos. Basically, these two elements are different but they are believed to have similarities and influence each other in a concept of rwabineda/duality. According to Puja (1978), the differences that exist are the human body as the micro cosmos and the universe as the macro cosmos, but both of them are formed from the same elements. Ardana (1982) states that humans as micro-cosmos are also referred to as bhuana alit, while the universe as a macrocosm is also called a bhuana agung. These two forms must always establish harmony to maintain harmony. Vertical holiness that raises the pros and cons in the construction of multistorey buildings should be carried out indepth studies so that harmony of the macro cosmos (bhuana agung) with the micro cosmos (bhuana alit) is maintained.

\subsection{Lontar Purwaka Weda, Surya Sewana, and Lontar Surya Mandala}

Vertical holiness turns out to have a definite limit according to what is stated in the Lontar Purwaka Veda and Lontar Surya Sewana is twelve Guli above the crown. The distance of twelve Guli is the area that must be maintained purity, while one Guli according to Astakosala-Kosali in the concept of development in Bali is a distance/length of the second segment of the index finger (Saraswati, 2002). The size of the finger used is the finger of the head of the family or those who are considered the oldest or who are elder in a family. In general, the length of the second index finger is an average of $2.5 \mathrm{~cm}$, so twelve Guli are equal to $30 \mathrm{~cm}$. In other lontar namely Lontar Surya Mandala, it was found the holiness limit is one cubit, while satau Hasta in Asta Kosala-Kosali is the length of the arm from the tip of the 
elbow to the tip of the straight position. If it is measured by the length of the arm of an average of around 35 to $45 \mathrm{~cm}$, then if the middle is taken $40 \mathrm{~cm}$, so the difference between one palm to another is not too far.

\section{RESEARCH METHOD}

\subsection{Study Sites}

Determining the location of the study is very important to note several things such as: the location of the study has built many multi-storey buildings, there are several activities that are building multistorey buildings, and seeing from the prospect of further building new buildings that are possible. Badung Regency was chosen as the location of the study because this area has quite a lot of multi-storey buildings such as Nusa Dua tourist settlement complex, Unud Campus in Jimbaran, Kuta tourist destination, Badung Government Center, and several other places. The location that is being built is also quite a lot, such as office development for Badung Puspem, development of tourist attractions in South Kuta, development of the Benoa Sea Port, and many others. The future development of Badung Regency has many locations with high prospects for the construction of multi-storey buildings such as: development of Uluwatu attractions, evening agro-tourism development, and others.

\subsection{Data Sources}

The data needed for the analysis is then obtained from several ways and sources such as:

1. Observation by making direct observations of several study objects and documenting all data obtained in the field.

2. Conducting interviews directly with several respondents, especially those who are considered to understand the topic under study.

3. Documentation, all data collected is made in the form of photos, reports, short films, etc.

4. Questionnaire, in the form of a questionnaire consisting of several questions that can be directly answered by respondents according to their understanding of the things being studied.

\subsection{Procedure/Steps for Study}

Some of the steps in the procedure in this study are as follows:

1. The first stage

Conducting observations and investigations and examining 
problems about vertical holiness that is understood by the community related to their role in multi-storey building design. Approaching the stakeholders/community leaders who understand vertical holiness, and then interviewing them to get their opinions on the topic to be studied. Conducting literature studies on vertical holiness, especially about the previous researches or studies that have been carried out by other researchers. Arranging the background and identifying the problem statement, and making goals, the benefits of the study to be carried out.

\section{Second stage}

Establishing the variables that will be used in this study, then the necessary research instruments can be made including the preparation of questionnaires that will be used to input data.

\section{Third stage}

Secondary data collection is needed; then it can be circulated by filling out questionnaires and conducting more intensive interviews with related parties so that vertical holiness data are collected which are needed for further analysis.

\section{Fourth stage}

Performing data analysis and processing and conclusions are drawn from the studies carried out and contained in a complete report.

\subsection{Data Analysis}

The processes of data analysis are carried out in this study as follows:

1. The qualitative analysis method which begins with the identification of vertical holiness in spatial aspects, is then associated with the influence of multi-storey design. Starting with theoretical studies to obtain a theoretical framework to be used as a guide in conducting interviews with Hindu experts/scholars.

2. Vertical holiness data obtained from palm leaves and interview results are associated with multi-storey building design, translated in the form of questionnaire questions which are then filled in by the respondents. Data from the results of filling out this questionnaire are then processed 
with a descriptive approach, and subsequent analysis is carried out to be able to draw conclusions about the role of vertical holiness in the design of multi-storey building infrastructure.

\section{RESULT AND DISCUSSION}

As a local wisdom, vertical holiness in relation to multi-storey building design should be studied in various aspects, especially from a religious and cultural perspective. Local wisdom is certainly very thick with the basic life of a society supported by culture and belief in embracing a religion. In Bali between Hinduism and Religion are two things that have been integrated in the life of the community so that both are often used as the foundation of life in society. Vertical holiness in relation to spatial planning is often calculated against the arrangement of upakara layout in religious ceremonies, the arrangement of the layout of buildings both for daily needs and the layout of buildings when there are traditional ceremonies or religious ceremonies.

\subsection{Scholarly Opinions about Vertical Holiness Are Associated with Multi-storey Building Design}

Based on the results of the interviews with experts/scholars or community leaders who are in charge of and understand this, the interrelationship of vertical holiness to multi-storey building design are as the following:

1. There is indeed a relationship between vertical holiness and the building structure for the sake of rest and for the purposes of ceremonies. As for the multistorey building, the height of each floor to be designed meets the requirements of vertical holiness.

2. In writing, the holiness limit is contained in the palm leaf and as a traditional leader, Sulinggih has applied this to both the interests of religious ceremonies and daily life. The height of the floor space of a multi-storey building must be made at least as high as the head of the household (the oldest occupant) plus a vertical height of one Hasta holiness.

3. Admittedly there is still a narrow fanaticism from some people who do not want to enter the downstairs; therefore, it needs more in-depth socialization of the meaning of vertical holiness and the high 
design of each floor's space should follow the limits of vertical purity. If not possible, then alternative designs should be made such as by making stairs that are outside the building.

\subsection{Linkage of Vertical Holiness with Multi-storey Building Design}

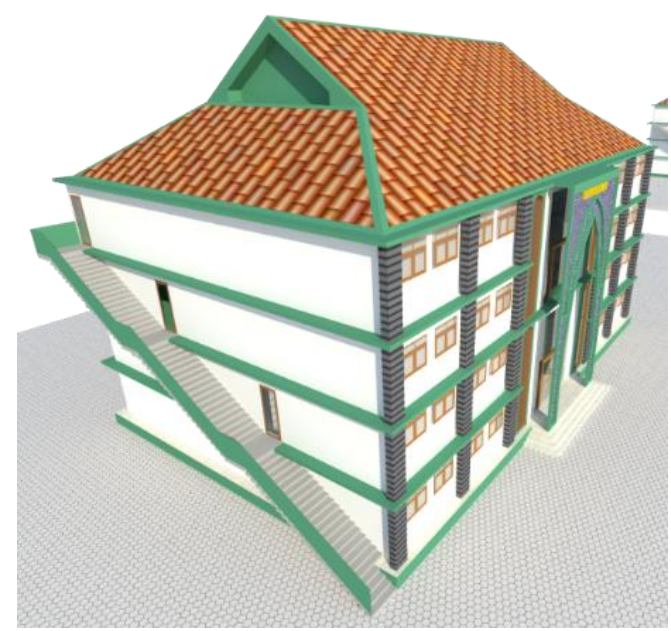

Figure 1. Multi-storeyBuilding with Outside Staircase Design.

If a multi-storey building has been designed by incorporating elements of vertical holiness requirements, then it will be continued by socializing the vertical holiness. If the understanding is correct about vertical holiness, then there is really no reason not to enter the embankment to the lower floors of a multi-storey building. As what has been explained by several stakeholders, vertical holiness is something that is also related to feelings. If the feeling is not willing to enter the place because it feels like it will be scary/lethargic, then there should not be coercion in this case. To overcome this, then try to make the design of making a ladder outside the building so that when going up to the top room (fourth floor) there is no stepping over so that there is no sense of lethargy. For buildings that are used for many people such as halls, offices, etc., a building design can also be made with the installation of elevators outside the building, so when you want to go up to the fourth floor you can go directly through the elevator without anyone stepping over to avoid taste, like the following picture:

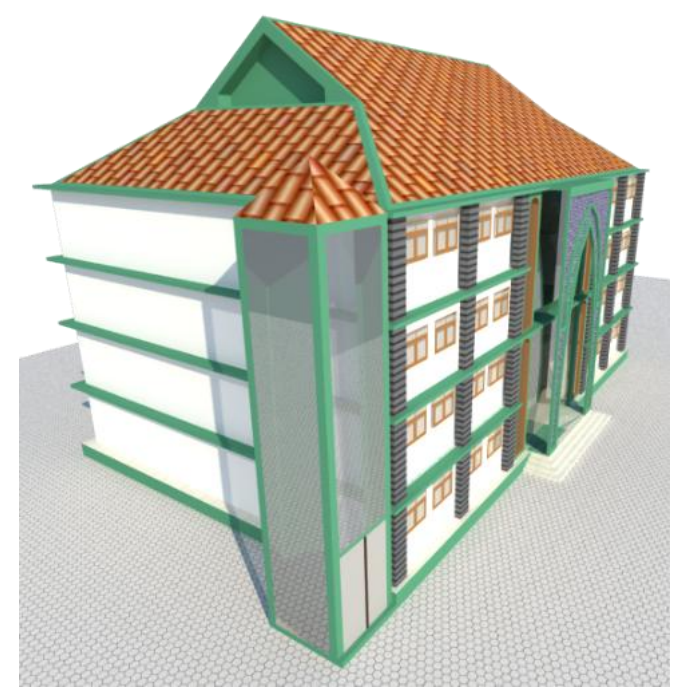

Figure 2. Building on the Fourth Floor with an Elevator Design Outside.

Based on the results of the analysis and interviews of the stakeholders, some of the things that need attention regarding the vertical holiness in multi-storey building design are as follows: 
1. Not all people understand vertical holiness, so more information is needed, but caution is needed because this is very sensitive.

2. If the socialization has been carried out and there are still stumbling blocks due to feelings, then a staircase design and/or elevator can be made outside the building so that the passing lower floor (mesulub) does not occur or there is no stepping over.

Of the overall opinions both those who are willing to do mesulub and those who are not, including the existence of regulations that limit the height of multistorey buildings, then all of that will be answered by time. If it is indeed able to survive to not want the machine, then as long as the belief is still there and there is no alternative to do it, and as long as there is no chance to enter the multi-storey building. Likewise with the existing regional regulations, if it turns out that the land has been used up for development in the horizontal direction, then it will remain without building in a vertical direction? Therefore, only time will be able to answer it.

\section{CONCLUSION}

From the description of the background, analysis and discussion above, it can be concluded as follows:

1. It is needed further data collection related to people's understanding of vertical holiness so that in carrying out socialization or other activities can be more detailed.

2. The design of the height of each floor of a multi-storey building should be guided by a minimum height limit of vertical holiness.

3. If after socialization but there are still those who argue that they cannot accept it, then it can be done by making stair and elevator designs outside the building.

4. By understanding vertical holiness, the determination of existing regulations will be tested by time so that only time will answer all events in this world.

Based on the conclusions drawn up, the following suggestions can be submitted:

1. In order for this program to succeed more quickly, more socialization was multiplied on 
various occasions and carried out the focus of the discussion group.

2. If a formula for the minimum height of vertical holiness has been found, it should be stated in legal form/regulation so that it can be clearly understood and accepted by the community.

3. Various alternatives such as the design of stairs outside the building need to be made as a way out so that development does not stop.

4. If later the time has demanded a change, then the community must be willing to change according to the demands of time.

\section{REFERENCES}

Anonymous, Lontar Purwaka Weda, Belongs to Drs. I. B. Gede Budayoga, M.Si; Grya Basang Tamiang, Kapal, Mengwi, Badung, Bali.

Anonymous, Lontar Surya Sewana, Belongs to Drs. I .B. Gede Budayoga, M.Si; Grya Basang Tamiang, Kapal, Mengwi, Badung, Bali.

Anonim, Lontar Swamandala, Belongs to my Jro Mangku Ketut Tinglis; Pemangku Gede Pura Desa, Adat Village Abianbase, Mengwi, Badung.
Ardana. (1982). Hinduism and the Environment, Project for Seminar on Unity of Interpretation of the Aspects of Hinduism, Denpasar.

Fairus, M.D, Ahmed, A.Z., \& Latif, M.T. (2011). Teracced Residential Indoor and Outdoor Housing Air Quality in Shyah Alam, Malaysia. In Proceedings of $3^{\text {rd }}$ International Symposium \& Exhibition in Sustainable Energy \& Environment (ISESEE), 204-208. Melaka: IEEE.

Feng, C.H., Chiang, C.M., Lin, F.M., \& Chung, S.C. (2011). Measurement and estimation on sound insulation performance of the walls and floors in Taiwan's dwelling-housings. 2011 International Conference on Multimedia Technology, 1106-1109.

Med, A., Stang, R., \& Florineth, F. (2017). Vertical Greening System - A Review on Recent Technologies and Advanced Research. Building and Environment, 125, 227-239.

O'Sullivan, A., \& Steven, M. S. (2003). Economics: Principles in action. Upper Saddle River, New Jersey 07458: Pearson Prentice Hall.

Provincial Government of Provinsi Bali. (2009). Bali Provincial Regulation No. 16 of 2009 concerning: Bali Provincial Spatial Plan 2009 - 2029. Denpasar: Ka. Bali Province Law \& Ham Bureau.

Puja, (1978). Implementation of P4 for Hindu Dharma. Jakarta: Director General of Hindu and Buddhist Bimas, Ministry of Religion.

Saraswati, A.A.A.O. (2002). Pamesuan $2^{\text {nd }}$ Edition. Jimbaran-Bali: Udayana University.

Zaki, W.R.M., Nawawi, A.H., \& Ahmad, S.S. (2011). Indoor Environmental Conditions in PassiveArchitecture 
Terraced House. In Proceedings of $3^{\text {rd }}$ International Symposium \& Exhibition in Sustainable Energy \& Environment (ISESEE), 204-208. Melaka: IEEE. 